\title{
The Effect of Reality Group Counseling with Confrontation and Metaphorical Techniques in Reducing Students' Hooky Behaviors of SMP Negeri 2 Wawonii Timur, Sulawesi Tenggara
}

\author{
La Ode Alibin Rilangit Saputra', Mulawarman², Awalya ${ }^{3}$ \\ ${ }^{1,2,3}$ Counseling and Guidance Study Program, Universitas Negeri Semarang, Central of Java, Indonesia.
}

Corresponding Author: La Ode Alibin Rilangit Saputra

DOI: https://doi.org/10.52403/ijrr.20220231

\begin{abstract}
Hooky behavior is a condition of students who behaved without respecting the school rules and regulations. The purpose of this study was to examine the effectiveness of group reality counseling with confrontational and metaphorical techniques in reducing students' hooky behavior. This study used a pretest and multiple posttest design. The intentional sampling technique had used to select 24 experimental subjects inserted into three groups randomly so that each group was composed of 8 students. The data was collected using a hooky behavior scale. The method of analyzing data used mixed repeated measure ANOVA. The results test of mixed repeated measure ANOVA showed that group of reality counseling with confrontational and metaphorical techniques was effective in reducing the students' hooky behavior with values of $(\mathrm{F}(2)=8.83, \mathrm{p}<0.01)$. There was an interaction effect between the time and the group on the students' hooky behavior with values of $(F(4.2)=(19.40, p<0.05)$. In conclusion, this study showed that confrontation and metaphorical techniques showed a complete change, so using this combined technique in counseling practice was recommended in reality group counseling.
\end{abstract}

Keywords: Reality Group Counseling, Confrontation, Metaphorical, Hooky Behaviour

\section{INTRODUCTION}

Hooky behavior had interpreted as students who intentionally leave school before completing the teaching and learning process. Kanga (2015, p. 1) explained that hooky behavior is students intentionally leaving school without teacher permission or parental approval. Gosain (2013, p. 13) supported that hooky behavior is the absence or leaving school without permission related to external factors starting from living conditions, family problems, society involvement, and classmate intimidation. Inherently, every student must behave based on the regulation applied and established in their school. But another situation in school was students' obedience to various kinds of rules and regulations; sometimes, students deliberately violate the laws, regulations, and various other provisions, resulting in students who skip school.

Behavioral changes had related to students' hooky behavior must be directed to take development in a more meaningful direction so that students can be accountable for all actions taken. Following the assumption of reality, group counseling required the students to be responsible for every decision made to minimize hooky behavior. One of the directions of approach to reality counseling was to lead students to emphasize choices to be fully accountable for every action and decision made. By group counseling, students can get positive information updates to reduce their hooky 
behavior (Puluhulawa, 2017). So, the intervention used a realistic approach through group counseling, leading students toward awareness of their obligations and responsibilities (Cahyani et al., 2020).

One of the appropriate interventions to solve this problem had applied reality group counseling through confrontation and metaphorical techniques. The use of confrontation and metaphorical methods in the realistic approach was a direct technique where the counsellor challenged the client to face themselves authentically and emphasize planning and commitment in behavioral plans that were difficult to change. Reality confrontation therapy helped clients plan and engage in challenging behavior to change and often did not go as planned. The use of confrontation and metaphorical techniques in reality approaches therapy did not criticize or debate clients but tried to explore the whole behavior and then made an effective plan to optimize the counseling implementation (Sharf, 2012). Besides the confrontation techniques in counseling reality, a method that was also effective to use in reality counseling, namely the metaphorical method. According to Mashar (2017), the metaphor technique was an effort to facilitate and build relationships between students and counsellors through creating meaning indirectly so that students quickly gain new enlightenment.

Based on the statements above, this study had expected to test the effectiveness of reality group counseling by using confrontation and metaphorical techniques to reduce students' hooky behavior. The difference between this study and the previous one was through confrontation and metaphorical techniques in the actual group counseling process, so it had expected to change counseling intervention.

\section{MATERIALS \& METHODS}

This study used a quantitative method with an experimental design of Randomized Pretest Posttest Comparison Group Design. According to Purwanto (2016), Randomized Pretest Posttest Comparison Group Design was suitable for internal validity threat control. An experimental subject had selected based on the students' hooky behavior category of 24 students. The assignment had made for each placement of 8 students in an experimental group that had given the treatment of reality group counseling intervention with confrontation and metaphorical techniques. The technique of data collection using a hooky behavior scale of 23 items had studied by Claudia E. Van Der Put (2020).

\section{RESULT}

The results of descriptive analysis data in this study showed that the mean level and standard deviation of hooky behavior in pretest confrontation group was $(\mathrm{M}=77.50 ; \mathrm{SD}=2.927)$ to posttest was $(\mathrm{M}=$ 47.62; $\mathrm{SD}=1.955)$ and follow up $(\mathrm{M}=$ 47.62; $\mathrm{SD}=1.955$ and score pretest on Metaphorical group was $(\mathrm{M}=79.62 ; \mathrm{SD}=$ $2.326)$ to posttest $(\mathrm{M}=50.12 ; \mathrm{SD}=4.793)$ and follow up $(\mathrm{M}=50.12 ; \mathrm{SD}=4.793)$. In the combination group, there was an average increase from pretest $(M=80.00$; $\mathrm{SD}=1.690)$ to posttest $(\mathrm{M}=42.12 ; \mathrm{SD}=$ $1.264)$ and follow up $(\mathrm{M}=42.12 ; \mathrm{SD}=$ 1.264), from the descriptive statistical analysis results for the whole score indicated that the mean values were high than standard deviation, so it showed a good presentation for the data spread. This result showed that the combination technique was higher than confrontation and metaphorical groups. For more information, the result will present in Table 1 below.

Table 1. Results of Descriptive Data Analysis

\begin{tabular}{|l|l|l|l|l|l|l|l|}
\hline Variable & Measurement & \multicolumn{2}{|c|}{ Confrontation } & \multicolumn{2}{c|}{ Metaphorical } & \multicolumn{2}{c|}{ Combination } \\
\cline { 3 - 8 } & & Mean & SD & Mean & SD & Mean & SD \\
\hline \multirow{3}{*}{ Hooky Behavior } & $\mathrm{T}_{1}$ & 77.50 & 2.927 & 79.62 & 2.326 & 80.00 & 1.690 \\
\cline { 2 - 8 } & $\mathrm{T}_{2}$ & 47.62 & 1.995 & 50.12 & 4.793 & 42.12 & 1.246 \\
\cline { 2 - 7 } & $\mathrm{T}_{3}$ & 47.62 & 1.995 & 50.12 & 4.793 & 42.12 & 1.246 \\
\hline
\end{tabular}


The results analysis of mixed ANOVA showed an effect of time on students' hooky behavior (f $(2=22733.541$; $\mathrm{p}<0.01)$. Furthermore, there was a group effect on the decrease in the students' hooky behavior and found a significant difference (f $(2)=8.83, p<0.05)$. Other results also demonstrated that there was an effect of temporal interaction with the group on the decrease of students' hooky behavior (f (4.2) $=19.40, \mathrm{p}<0.05)$. It will present in Table 2below.

Table 2. Results of Mixed ANOVA Analysis

\begin{tabular}{|l|l|l|l|}
\hline \multirow{2}{*}{ Effect } & \multicolumn{3}{|c|}{ Hooky's Behavior } \\
\cline { 2 - 4 } & F & Df & P \\
\hline Time & 2733.541 & 1,2 & $<0.01$ \\
\hline Groups & 8.83 & 2 & $<0.05$ \\
\hline Time*Groups & 19.40 & 4,2 & $<0.05$ \\
\hline
\end{tabular}

The results of pairwise comparison analysis showed that (T1 - T2), (T1 - T3), and (T2 - T3) from each experimental group had increased. It concluded that there was a decrease in students' hooky behavior in each measurement. The groups' improvement levels in each measure will present in Table 3 below.

Table 3. Results of Pairwise Comparison of Confrontation, Metaphorical, and Combination Techniques

\begin{tabular}{l} 
Metaphorical, and Combination Techniques \\
\begin{tabular}{|l|l|l|l|}
\hline Measurement & Mean & SE & P \\
\hline Confrontation Technique of Experimental Group \\
\hline $\mathrm{T}_{1}-\mathrm{T}_{2}$ & 77.500 & 0.838 & $<0.01$ \\
\hline $\mathrm{T}_{1}-\mathrm{T}_{3}$ & 47.625 & 1.090 & $<0.01$ \\
\hline $\mathrm{T}_{2}-\mathrm{T}_{3}$ & 47.625 & 1.090 & $<0.01$ \\
\hline \multicolumn{4}{|c|}{ Metaphorical Technique of Experimental Group } \\
\hline $\mathrm{T}_{1}-\mathrm{T}_{2}$ & 79.625 & 0.838 & $<0.01$ \\
\hline $\mathrm{T}_{1}-\mathrm{T}_{3}$ & 50.125 & 1.090 & $<0.01$ \\
\hline $\mathrm{T}_{2}-\mathrm{T}_{3}$ & 50.125 & 1.090 & $<0.01$ \\
\hline & $\mathrm{C}_{2}$ bination Technique of Experimental Group \\
\hline $\mathrm{T}_{1}-\mathrm{T}_{2}$ & 80.000 & 0.838 & $<0.01$ \\
\hline $\mathrm{T}_{1}-\mathrm{T}_{3}$ & 42.125 & 1.090 & $<0.01$ \\
\hline $\mathrm{T}_{2}-\mathrm{T}_{3}$ & 42.125 & 1.090 & $<0.01$ \\
\hline
\end{tabular} \\
\hline
\end{tabular}

The result above found the effectiveness differences between time and interaction with confrontation technique, metaphorical technique, and combination technique groups. The upshot of this study indicated that the three techniques effectively reduced students' hooky behavior. It concluded that there was a change in behavioral and self-controlled of their behavior. Although the three techniques effectively reduced students' hooky behavior, each method had a different level of effectiveness. In this study, counseling services with combination techniques decreased students' hooky behavior more effectively than confrontation and metaphorical approaches, although no significant differences were.

\section{DISCUSSION}

Based on the result explained, this study showed that the effectiveness of the techniques was following the primary goal of using reality counseling was that each individual can be responsible for their own choices (Cappuzi \& Stauffer, 2016). On the application, confrontation techniques helped the consultant to change their behavior to be congruent live a life according to healthier function (Corey, 2015). According to MacCluskie (2010), the confrontation technique was effective when introducing intuition and awareness, overcoming resistance, increasing congruence between client's goal and behavior, promoting open communication, and leading to positive changes in emotions and thoughts. The use of the second technique was metaphorical technique. Tompkins (in Chapman, 2009) generally, the metaphorical technique was defined as a speaking technique about one thing expressed in another. It was in line with Mashar (2017) stated that metaphorical technique was an effort to facilitate and build relationships between fellow students and counselors through indirect creation of meaning so that students could quickly gain new enlightenment.

Furthermore, this study's results became more effective by combining two techniques of reality counseling: confrontation and metaphorical techniques. The combination technique had considered more effective to apply in reality group counseling than just using one method. It was in agreement with the study findings of Tahrani et al. (2019), which used a combination of problem-solving and roleplaying techniques which stated that these two techniques combined produce an effective result compared to using one 
method. It was supported in another study using a combination technique conducted by Rani et al. (2018), revealing that self-talk and reframing had the same effectiveness level, as shown by the study results on differences in the level of effectiveness. Although this study showed the same results, it was still effective in using a combination technique compared to only one method.

Based on the study's findings, the implication for counseling and guidance teachers was that reducing students' hooky behavior can use confrontation and metaphorical techniques in reality group counseling. Furthermore, using combination techniques in counseling practice was highly recommended in implementing reality group counseling. The counseling and guidance teachers had expected to open the space to cooperate with related parties (parents and schools) in reducing students' hooky behavior so that the implementation of counseling and guidance could function effectively and efficiently.

\section{CONCLUSION}

Based on the outcome was found in this study, it concluded that reality group counseling, confrontation, and metaphorical techniques effectively reduced students' hooky behavior of SMP Negeri 2 Wawonii Timur. Based on the results of this study, counsellors had suggested using reality group counseling and metaphorical techniques in reducing students' hooky behavior. Meanwhile, further researchers could broaden the research subjects in their study so that the study results applied to a large area, not just one school. Future researchers should also research differences in the level of hooky behavior between female students and male students.

\section{Acknowledgement: None}

\section{Conflict of Interest: None}

Source of Funding: None

\section{REFERENCES}

1. Cahyani, A.I., Wibowo, M.E., \& S. (2020). Reality Group Counseling to Increase Emotional Intelligence and Happiness. Jurnal BimibnganKonseling, 9(1)(71-78).

2. Cappuzi, D., \& Stauffer, M. D. (2016). Counseling and Psychotherapy: Theories and Interventions (Sixth Edit).

3. Corey, G. (2015). Theory and Practice of Counseling and Psychotherapy. Belmont, CA: Cengage

4. Chapman, R. D. (2009). "The Use of Metaphor in Counseling: A Discourse Analysis." A Thesis Submitted: Counseling Psychology. Columbia: University of British.

5. Claudia E. van der Put. (2020). The development of a risk and needs assessment instrument

fortruancy.journalhomepage:www.elsevier.c om/locate/childyouth.https://doi.org/10.101 6/j.childyouth.2019.104721

6. Gosain, N.C. (2013). A Study of the factors leading to truancy among adolescent students in district Faridabad. IOSR Journal of Research \& Method in Education (IOSRJRME) e-ISSN: 2320-7388,p-ISSN: 2320737X Volume 1, Issue 6 (May. - Jun. 2013), PP 13-19 www.iosrjournals.org

7. Kanga, B. M. (2014). Factors Contributing to Truancy in Secondary Schools in Meru South District, Kenya. International Journal of Scientific and Research Publications, 5(1), 2250-3153. www.ijsrp.org

8. Mashar, R. (2017). Story In Reducing Childhood Aggression Behavior. Proceeding International Conference PIAUD., ISBN: 978-602-0868-80-6.

9. MacCluskie, K.C. (2010). Acquiring Counseling Skills: Integrating Theory, Multiculturalism, and Self-awareness. Upper Saddle River, NJ: Pearson/Merrill.

10. Puluhulawa, M., et. al. (2017). Reality Group Counseling to Improving SelfEsteem of Students. GUIDENA: Jurnal Ilmu Pendidikan, Psikologi, Bimbingan Dan Konseling, Vol 7(153-157. ISSN : 20889623 (Print).). https://doi.org/DOI: 10.24127/gdn.v7il.859.

11. Purwanto, E. (2015). Metodologi Penelitian Kuantitatif. Yogyakarta: Pustaka Pelajar.

12. Sharf, R. (2012). Theories of Psychotherapy and Counseling Concepts and Cases.Brooks/ColeA Division of Cengage Learning, Inc. United States America. 
La Ode Alibin Rilangit Saputra et.al. The effect of reality group counseling with confrontation and metaphorical techniques in reducing students' hooky behaviors of SMP Negeri 2 Wawonii Timur, Sulawesi Tenggara.

13. Rani, A. P., Sutoyo, A., \& Awalya, A. (2018). The effectiveness of group counseling with self-talk technique and combination of self-talk and reframing technique to reduce aggressivity. Jurnal Bimbingan Konseling, 7(1), 69-74. Retrieved from: https://journal.unnes.ac.id/sju/index.php/jub $\mathrm{k} /$ article/view/22841

14. Taharani, A. F., Wibowo, M. E., \& Mulawarman. (2019). The effectiveness of cbt group counseling with problem-solving and role-play techniques to improve students" emotional intelligence. Jurnal
Bimbingan Konseling, 10(1), 34-39.

Retrieved from:

https://journal.unnes.ac.id/sju/index.php/jub $\mathrm{k} /$ article/view

How to cite this article: La Ode Alibin Rilangit Saputra, Mulawarman, Awalya. The effect of reality group counseling with confrontation and metaphorical techniques in reducing students' hooky behaviors of SMP Negeri 2 Wawonii Timur, Sulawesi Tenggara. International Journal of Research and Review. 2022; 9(2): 224-228. DOI: https://doi.org/10.52403/ijrr. 20220231 